\title{
Chicago-Kent Journal of International and Comparative Law
}

\section{The Likelihood of Turkey's Accession into the European Union: A Controversial Inquiry}

Ashleigh Hebert

Follow this and additional works at: https://scholarship.kentlaw.iit.edu/ckjicl

Part of the Law Commons

\section{Recommended Citation}

Ashleigh Hebert, The Likelihood of Turkey's Accession into the European Union: A Controversial Inquiry, 13 Chi.-Kent J. Int'I \& Comp. Law 1 (2012).

Available at: https://scholarship.kentlaw.iit.edu/ckjicl/vol13/iss1/1

This Article is brought to you for free and open access by Scholarly Commons @ IIT Chicago-Kent College of Law. It has been accepted for inclusion in Chicago-Kent Journal of International and Comparative Law by an authorized editor of Scholarly Commons @ IIT Chicago-Kent College of Law. For more information, please contact jwenger@kentlaw.iit.edu, ebarney@kentlaw.iit.edu. 


\title{
Article
}

\section{The Likelihood of Turkey's Accession into the European Union: A Controversial Inquiry}

\author{
Ashleigh Hebert ${ }^{*}$
}

Table of Contents

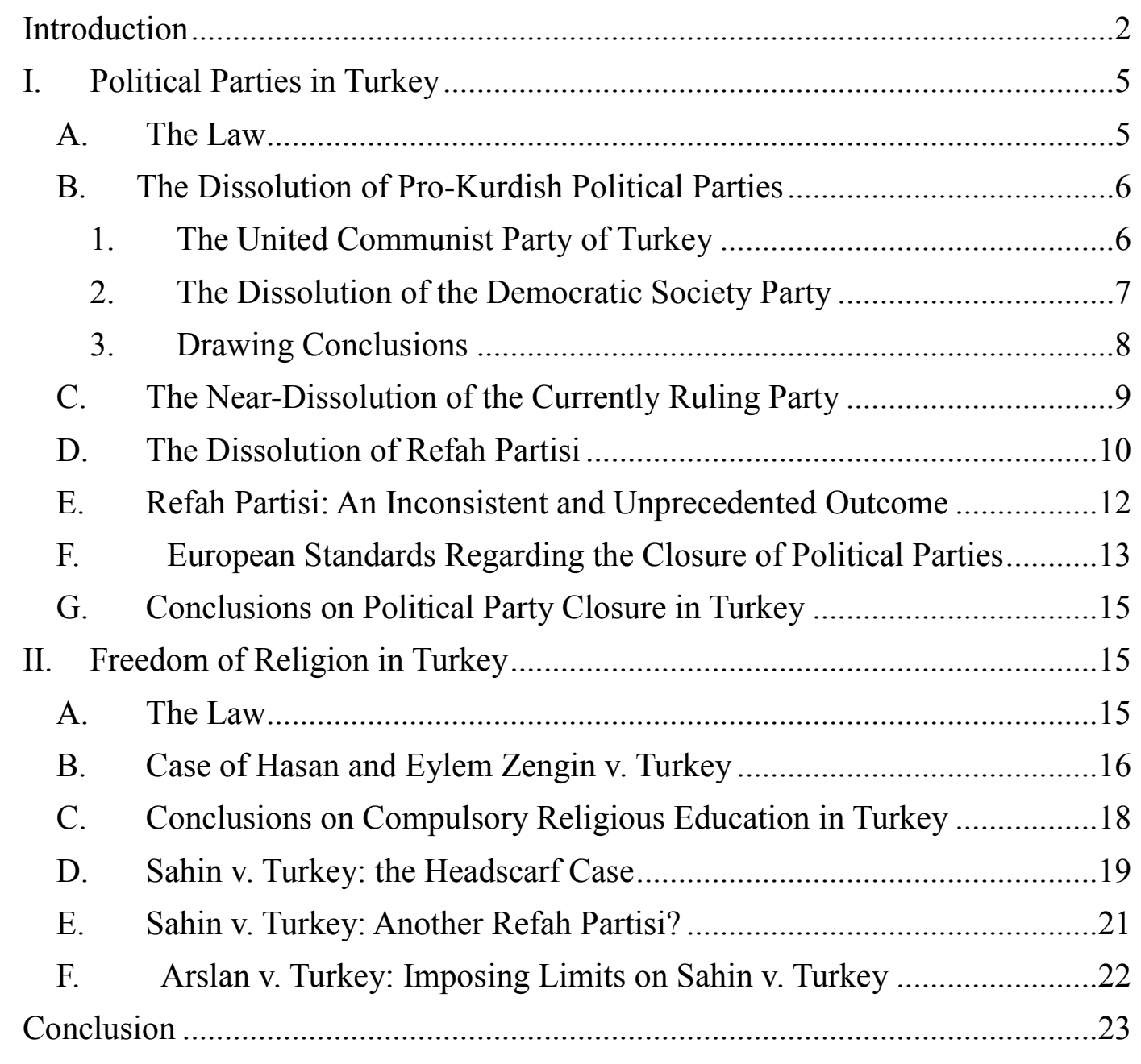

\footnotetext{
* Ashleigh Hebert is currently a student at the Benjamin N. Cardozo School of Law. In addition to her current position at the Cardozo Tax Clinic, Ms. Hebert has interned with the Pennsylvania Supreme Court and held positions at Herskovits PLLC, the Kenmar Group, and Mintz \& Fraade, P.C.
} 


\title{
The Likelihood of Turkey's Accession into the European Union: A Controversial Inquiry
}

\author{
Ashleigh Hebert
}

\section{Introduction}

The European Union ("EU") is an unparalleled economic and political partnership composed of twenty-seven European member states. ${ }^{1}$ The EU was originally implemented to create an economic community, whereby member states would become interdependent on one another. ${ }^{2}$ The hope was that this interdependence would discourage conflict, as war would become catastrophic. ${ }^{3}$ Over time, this community evolved into a supranational organization with not only economic objectives, but social, cultural, political, and international objectives as well. ${ }^{4}$ Since its formation, the European Union has experienced enduring success and unity, ${ }^{5}$ and has grown from six members in 1952 to twenty-seven members, as of December 26, 2012. ${ }^{6}$ This number excludes one acceding country, five candidate countries, and three potential candidate countries. ${ }^{7}$

To become a member of the European Union, a country must go through a rigorous screening process. ${ }^{8}$ To begin the process, a European state that "respects the principles of liberty, democracy, respect for human rights and fundamental freedoms, and the rule of law" may submit an application to the Council of the European Union ("Council"). ${ }^{9}$ If the Council accepts the application, the country then becomes a candidate country, and accession negotiations begin. ${ }^{10}$ However, acceptance is not automatic; for the Council to approve the application, the candidate country must have stable democratic institutions, the rule of law, respect for human rights and minorities, a functioning market economy, a government that is able to assume the obligations of membership and that can implement EU rules and procedures into their domestic

${ }^{1}$ Basic Information on the European Union, EUROPEAN UNION, http://europa.eu/about-eu/basicinformation/index en.htm (last visited Feb. 1, 2013).

${ }^{2} / d$.

${ }^{3} / d$.

${ }^{4}$ See id.

${ }^{5}$ Countries, EUROPEAN UNION, http://europa.eu/about-eu/countries/index_en.htm (last visited Feb. 1, 2013).

${ }^{6}$ Enlargement, EUROPEAN UNION, http://ec.europa.eu/enlargement/policy/from-6-to-27members/index_en.htm (last updated Sept. 24, 2012).

${ }^{7}$ Check Current Status, EUROPEAN UNION, http://ec.europa.eu/enlargement/countries/checkcurrent-status/index_en.htm (last updated Dec. 18, 2012).

${ }^{8}$ Conditions for Membership, EUROPEAN UNION,

http://ec.europa.eu/enlargement/policy/conditions-membership/index_en.htm (last updated Sept. 13, 2012).

${ }^{9} / d$.

${ }^{10} / d$. 
laws. ${ }^{11}$ If the Council unanimously agrees that the candidate country has met these conditions (the "Copenhagen criteria"), accession negotiations will begin. ${ }^{12}$

To conclude the next stage, negotiations must be conducted in thirty-five separate chapters. ${ }^{13}$ Each of these chapters is geared towards a particular subject matter with the goal of aligning the candidate country's laws with those of the acquis communautaire: the legislation, regulations, and cases that embody European Union law. ${ }^{14}$ A few examples of these chapters include the free movement of goods and workers, education and culture, and the environment. ${ }^{15}$ The European Commission examines each chapter to determine whether the candidate country is prepared for negotiations on that particular subject matter and recommends whether negotiations should be opened. ${ }^{16}$ Once a chapter is opened, negotiations are conducted with the candidate country, and the completion time depends on how quickly the country reforms its laws. ${ }^{17}$ Once all chapter negotiations are concluded and both sides are satisfied with the candidate country's progress, an Accession Treaty is drafted. ${ }^{18}$ This treaty must then be signed by all members of the European Union. ${ }^{19}$ After all member states and the candidate country ratify the treaty, it will enter into force, and the acceding country becomes a member state. ${ }^{20}$

Turkey is one of the five countries currently engaged in accession negotiations. ${ }^{21}$ Although Turkey and the European Union have experienced close relations since the signing of the Ankara Agreement in 1963, which brought Turkey into the customs union, ${ }^{22}$ Turkey's accession remains immensely controversial. The contentious nature of Turkey's accession largely stems from its Islamic heritage, which has caused the county to struggle with the separation of church and state. ${ }^{23}$ Although the Republic of Turkey was founded in 1923 on the notion that the state would be secular, ${ }^{24}$ the country has difficulty upholding this principle, as ninety-nine percent of the population is Muslim. ${ }^{25}$ Furthermore, there has been increasing

\footnotetext{
${ }^{11} / d$.

${ }^{12}$ Steps Towards Joining, EUROPEAN UNION, http:/ec.europa.eu/enlargement/policy/steps-towardsjoining/index_en.htm (last updated Oct. 10, 2012).

${ }^{13}$ Conditions for Membership, EUROPEAN UnION, supra note 8.

${ }^{14} / d$.

${ }^{15} / d$. Other elements of the acquis communautaire include intellectual property law, agriculture, taxation, social policy and employment, and external relations.

${ }^{16}$ Steps Towards Joining, supra note 12.

${ }^{17} / d$.

${ }^{18} / d$.

${ }^{19} / d$.

${ }^{20} / d$.

${ }^{21}$ Countries, supra note 5.

${ }^{22}$ Turkey, EUROPEAN UNION, http://ec.europa.eu/enlargement/countries/detailed-countryinformation/turkey/index_en.htm (last updated Oct. 10, 2012).

${ }^{23}$ See, e.g., Sahin v. Turkey, 2005-XI Eur. Ct. H.R., ๆ 30-32.

${ }^{24}$ Id. 30; TÜRKIYE CUMHURIYETI ANAYASASI [CONSTITUTION] Nov. 7, 1982, art. 2 (Turk.).

${ }^{25}$ Turkey, EUROPEAN UNION, http://europa.eu/about-eu/countries/candidatecountries/turkey/index_en.htm (last visited Apr. 9, 2012).
} 
public support for political parties that back theocratic governance, ${ }^{26}$ or alternatively, a plurality of legal systems categorizing individuals based on their religious beliefs. ${ }^{27}$ Given the overwhelmingly Muslim population and increased public support for alternative forms of governance, many individuals are concerned that Turkey will not fit in with the predominantly Christian Europe. ${ }^{28}$ Furthermore, many feel that Turkey should not be admitted into the European Union because it is not part of Europe, given its location as the "geographical and cultural bridge between Europe and the Middle East." 29

Unfortunately, due to this religious ambience, it is unlikely that Turkey will gain admission to the European Union in the near future. Turkey's struggle to lessen religious influence has resulted in a history of governmental suppression of individual, civil, and political rights in order to preserve the principles of secularism and democracy, particularly when it comes to freedom of association and freedom of religion. ${ }^{30}$ For example, Turkey has dissolved political parties in favor of theocratic governance and has prohibited women from wearing headscarves on university campuses. ${ }^{31}$ The European Court of Human Rights ("ECHR") has occasionally upheld the Constitutional Court of the Republic of Turkey's ("Constitutional Court") decisions, ${ }^{32}$ leading one to believe that Turkey's suppression of rights in favor of secularism and democracy is in conformity with European Union standards. However, the ECHR has consistently condemned Turkey for violations of freedom of association and freedom of religion. ${ }^{33}$

Furthermore, the European Commission likewise denounces Turkey's law regarding the closure of political parties and its failure to ensure religious freedom. ${ }^{34}$ Due to the importance of political parties "in view of their essential role in ensuring pluralism and the proper functioning of

\footnotetext{
${ }^{26}$ E.g., Ran Hirschl, Symposium: Constitutional Courts in the Field of Power Politics: Constitutional Courts vs. Religious Fundamentalism: Three Middle Eastern Tales, 82 TEX. L. Rev. 1819, 1849 (2004); see also Refah Partisi v. Turkey, 2003-II Eur. Ct. H.R.

${ }^{27}$ See Refah Partisi, 2003-II Eur. Ct. H.R., ๆ 28.

${ }^{28}$ See, e.g., Padideh Ala'i, Conference: Turkey: At the Crossroads of Secular West and Traditional East: Introduction, 24 AM. U. INT'L L. REV. 679, 680 (2009); Saying No to Turkey, N.Y. TIMES, Aug. 15, 2004; NATALIE ToCCI, TURKEY'S EUROPEAN FutURE: BeHIND THE SCENES OF AMERICA'S INFLUENCE ON EU-TURKEY RELATIONS 100-01 (N.Y. University Press 2011); W. COLE DURHAM, JR., ET AL., ISLAM, EUROPE AND EMERGING LEGAL ISSUES 301 (W. Cole Durham, Jr. et al. eds., 2012).

${ }^{29}$ Hirschl, supra note 26, at 1848.

${ }^{30}$ See, e.g., Sahin v. Turkey, 2005-XI Eur. Ct. H.R.; Refah Partisi, 2003-II Eur. Ct. H.R.; United Communist Party of Turkey v. Turkey, 1998-I EuR. CT. H.R.; Shubra Ohri, Turkish Constitutional Court Bans Kurdish Political Party, Turkey's Largest Minority Group Loses its Political Voice, HUMAN RIGHTS BRIEF (Feb. 2, 2010), http://hrbrief.org/2010/02/turkish-constitutionalcourt-bans-kurdish-political-party/,

${ }^{31}$ See, e.g., Sahin, 2005-XI Eur. Ct. H.R.; Refah Partisi, 2003-II Eur. Ct. H.R.

${ }^{32}$ See, e.g., Sahin, 2005-XI Eur. Ct. H.R.; Refah Partisi, 2003-II Eur. Ct. H.R.

${ }^{33}$ See, e.g., Zengin v. Turkey, App. No. 1448/04, EUR. CT. H.R. (2008), http://www.echr.coe.int; Democracy and Change Party v. Turkey, App. No. 39210/98, Eur. Ct. H.R. (2005), http://www.echr.coe,int; United Communist Party, 1998-I Eur. Ct. H.R.

${ }^{34}$ Commission Staff Working Paper: Turkey 2011 Progress Report, at 9, 29-31, SEC (2011) 1201 final (Oct. 12, 2011); Commission Staff Working Document: Turkey 2010 Progress Report, at 7, 23-25, SEC (2010) 1327 final (Nov. 9, 2010).
} 
democracy" $^{\prime 35}$ and the consensus among democratic societies of the fundamental importance of freedom of religion, ${ }^{36}$ it is unlikely that the European Commission will open, let alone close, negotiations on the "judiciary and fundamental rights" chapter until Turkey protects these fundamental rights. ${ }^{37}$ In addition, even if this chapter is eventually closed, achieving a unanimous vote in favor of accession will become increasingly difficult as enlargement of the European Union continues. ${ }^{38}$ Moreover, several member states adamantly oppose Turkey's accession, including two original members: France and Germany. ${ }^{3}$

\section{Political Parties in Turkey}

\section{A. The Law}

In order to become a member of the European Union, it is imperative that Turkey amends its laws regarding the closure of political parties. Turkey's Constitution states that "[p]olitical parties are indispensable elements of democratic political life." ${ }^{40}$ However, Turkey's Constitution goes on to renounce this premise by indicating that:

The statutes and programmes, as well as the activities of political parties shall not be in conflict with the independence of the state, its indivisible integrity with its territory and nation, human rights, the principles of equality and rule of law, sovereignty of the nation, the principles of the democratic and secular republic; they shall not aim to protect or establish class or group dictatorship or dictatorship of any kind, nor shall they incite citizens to crime. ${ }^{41}$

If the Constitutional Court decides that a political party "has become a centre for the execution of" the activities prohibited in Article 68, it may dissolve the party. ${ }^{42}$ A political party is determined to have become a "centre for the execution" of such activities when members of the party carry out the actions intensively, the activities or views are shared by the decision-making or administrative organ of the party, or the activities are carried out directly by the decision-making or

\footnotetext{
${ }^{35}$ United Communist Party of Turkey, 1998-I Eur. Ct. H.R., 943.

${ }^{36}$ E.g., Sahin, 2005-XI Eur. Ct. H.R., $₫ 104$; JinghaO ZHou, ChINA'S PEACEFUl Rise IN a Global CONTEXT: A DOMESTIC ASPECT OF CHINA'S ROAD MAP TO DEMOCRATIZATION 165 (Rowman \& Littlefield Publishers, Inc. 2012); Freedom of Religion: Essential Principles, DEMOCRACY WEB, http://www.democracyweb.org/religion/principles.php (last visited Apr. 12, 2012).

${ }^{37}$ See Steps Towards Joining, supra note 12.

${ }^{38}$ Id.; Enlargement of the European Union Factsheet EUROPEAN UNION (2010), http://www.ec.europa.eu/enlargement/pdf/publication/elarg-factsheet_en.pdf.

${ }^{39}$ Martin Kettle, Disgracefully, Turkey's EU Accession Bid is Going Nowhere Soon, GuARDIAN, Oct. 28, 2010; Turkey's EU Bid on the Rocks as Tensions with Greek Cypriots Escalate, XINHUA, Oct. 3, 2011.

${ }^{40}$ TÜRKIYE CUMHURIYETİ ANAYASASI [CONSTITUTION] Nov. 7, 1982, art. 68 (Turk.).

${ }^{41} / d$.

${ }^{42}$ TÜRKIYE CUMHURIYETİ ANAYASASI [CONSTITUTION] Nov. 7, 1982, art. 69 (Turk.).
} 
administrative organ. ${ }^{43}$ The Constitutional Court has successfully banned twentyseven political parties based on the prohibited activities listed in Article $68 .^{44}$

\section{B. The Dissolution of Pro-Kurdish Political Parties}

\section{The United Communist Party of Turkey}

The Constitutional Court dissolved the United Communist Party ("TBKP") on July 16, 1991. ${ }^{45}$ The Court held that the mere mention of the word "communist" in the name of a political party was enough to dissolve the party under Section 96(3) of Law Number 2820. ${ }^{46}$ Moreover, because the party's program referred to two nations, the Kurdish nation and the Turkish nation, the TBKP could be dissolved for violating Article 68 of the Constitution by encouraging separatism and seeking to dismantle the unity of the nation. ${ }^{47}$ The Court came to this conclusion despite several passages in the party's program contradicting the Court's conclusion, such as:

The [United Communist Party] will strive for a peaceful, democratic and fair solution of the Kurdish problem, so that the Kurdish and Turkish Peoples may live together of their free will within the borders of the Turkish Republic, on the basis of equal rights and with a view to democratic restructuring founded on their common interests. ${ }^{48}$

Based on the above passage, it appears that the program seeks a society where the Kurdish and

Turkish people live together in peaceful coexistence. Thus, the inquiry become whether Turkey sought to ban the party solely because of its pro-Kurdish program.

The European Commission on Human Rights ("Human Rights Commission") was asked whether the dissolution constituted a violation of Article 11 of the European Convention on Human Rights, which protects freedom of association. $^{49}$ The Human Rights Commission began with the premise that dissolution constituted a violation of the parties' rights under Article 11. ${ }^{50}$ However, Article 11 also provides that "[n]o restrictions shall be placed on the exercise of these rights other than such as are prescribed by lawand

${ }^{43} / d$.

${ }^{44}$ Ohri, supra note 30 .

${ }^{45}$ United Communist Party of Turkey v. Turkey, 1998-I EUR. CT. H.R. ๆ 10.

${ }^{46} / d$.

${ }^{47} / d$.

${ }^{48} / d \cdot 99$.

${ }^{49} / d$. 17. Note that the European Commission on Human Rights has since become obsolete; the European Court of Human Rights was restructured so claims no longer have to go through the Commission before the European Court of Human Rights will hear the case- this institution will not appear elsewhere in this paper. The European Commission, on the other hand, is the executive body of the European Union and is active.

${ }^{50}$ United Communist Party, 1998-I Eur. Ct. H.R., 936. 
are necessary in a democratic society in the interests of national security or public safety, for the prevention of disorder or crime, for the protection of health or morals or the protection of the rights and freedoms of others." ${ }^{51}$ The Human Rights Commission thus indicated that the dissolution was permitted under the Constitution and several sections of Law Number 2820 on the regulation of political parties.

Next, the Human Rights Commission held that the dissolution was sought to pursue a legitimate aim: "the protection of "national security." 52 It reasoned that the program "could be regarded as openly pursuing the creation of a separate Kurdish nation and consequently a redistribution of the territory of the Turkish State." ${ }^{53}$ However, the Human Rights Commission concluded that the interference was not necessary in a democratic society as required by Article $11 .{ }^{54}$ It stated, "there can be no democracy without pluralism;" furthermore, freedom of expression is enshrined in the convention not only to favorably received ideas, but also those that "offend, shock, or disturb." ${ }^{55}$ Thus, government opposition to a solution to the Kurdish problem is insufficient to prevent society from debating the issue in public forum.

The ECHR came to the same conclusion, but took a more direct route. The Court noted that dissolution based on a political party's name was too drastic a measure absent other considerations. ${ }^{56}$ Next, the Court considered whether the party sought to promote separatism and division of the Turkish nation. $^{57}$ It held that the party merely sought recognition of the Kurds and peaceful coexistence between the Kurdish and Turkish peoples. ${ }^{58}$ It emphasized that an inherent characteristic of democratic society is the ability to resolve the nation's problems through dialogue; thus, there is no justification for disallowing discussion on the Kurdish problem. ${ }^{59}$ Given the above-cited considerations, the Court concluded that the Constitutional Court of Turkey violated Article 11 of the European Convention on Human Rights when it dissolved the United Communist Party. ${ }^{60}$

\section{The Dissolution of the Democratic Society Party}

The Democratic Society Party ("DTP"), another pro-Kurdish political party, was banned on December 11, 2009. ${ }^{61}$ The Constitutional Court of Turkey accused the DTP of having connections with the Kurdistan Workers' Party,

${ }^{51} / d .918$ (emphasis added).

${ }^{52} / d$. $\mid 41$.

${ }^{53} / d$. 940.

${ }_{55}^{54} / d$. 961.

${ }^{55} / d .943$.

${ }^{56} / d$. 95.

${ }^{57} / d$. 95.

${ }^{58} / d$. 56.

${ }^{59}$ Id. 957.

${ }^{60} / d$. ๆ 61.

${ }^{61}$ Ohri, supra note 30. 
a group considered a terrorist organization by the Turkish government. ${ }^{62}$ Because the Kurdistan Workers' Party has been fighting for Kurdish autonomy for several decades, the Court held that the Democratic Society Party could be dissolved for undermining national unity in violation of Article 68 of the constitution. ${ }^{63}$ This decision led to thousands of protesters taking to the streets because the Democratic Society Party was the only pro-Kurdish party recognized in the country at the time of dissolution. ${ }^{64}$

\section{Drawing Conclusions}

Based on these cases and the Kurdish population's long-standing struggle to achieve equality, it appears that the Turkish government will resist all efforts to debate the Kurdish situation in public forum. It is noteworthy that a large portion of the Kurdish population seeks a separate state through the exercise of the right of self-determination. ${ }^{65}$ Therefore, the government has a defendable position when it seeks to dissolve any pro-Kurdish political party, as Article 68 of the Constitution allows the Constitutional Court to dissolve a political party if its program, statutes, or activities are in conflict with the indivisible integrity of the nation. The government can thereby prevent pro-Kurdish parties from taking part in the political process by grouping all Kurdish Turks into the group that seeks to establish a separate state. This conclusion is strengthened in light of numerous other cases where the government dissolved a pro-Kurdish political party solely because of the party's desire to seek a solution to the Kurdish problem. $^{66}$ This pattern is both incomprehensible and demoralizing because "[w]ithout well-functioning parties, governments and legislatures have little chance of representing wider society in a meaningful way." ${ }^{67}$ Furthermore, Turkish Kurds constitute nearly twenty percent of the population; ${ }^{68}$ thus, by depriving one-fifth of the population of a voice, democracy is rendered meaningless. In light of the government's oppression of the Kurdish population, it appears the size of this minority has caused the Turkish government to consider the group to be a significant threat to the unity of the nation. $^{69}$

${ }^{62}$ Questions and Answers about the Case Against the Democratic Society Party, HUMAN RIGHTS WATCH (Dec. 10, 2009), http://www.hrw.org/en/news/2009/12/09/questions-and-answers-aboutcase-against-democratic-society-party.

${ }^{65}$ TÜRKIYE CUMHURIYETI ANAYASASI [CONSTITUTION] Nov. 7, 1982, art. 68 (Turk.).; Sebnem Arsu, Turkey Bans Kurdish Party, N.Y. Times, Dec. 11, 2009.

${ }^{64} \mathrm{Ohri}$, supra note 30.

${ }^{65} \mathrm{See}$, Kurds, COUNTRY STUDIES, http://countrystudies.us/turkey/28.htm (last visited Apr. 10, 2012).

${ }^{66}$ See, e.g., Democracy and Change Party, EuR. CT. H.R.; Dicle on Behalf of the Democratic Party v. Turkey, App. No. 25141/94, Eur. Ct. H.R. (2002), http://www.echr.coe.int Freedom and Democracy Party v. Turkey, 1999-VII EUR. CT. H.R.

${ }^{67}$ Peter Burnell, Building Better Democracies: Why Political Parties Matter, WeSTMINSTER FOUNDATION FOR DEMOCRACY (Dec. 2004), www.wfd.org/upload/docs/WFDBBD5 noprice.pdf. ${ }^{68}$ Ohri, supra note 30.

${ }^{69} \mathrm{Kurds}$, supra note 65. 
The dissolution of the United Communist Party of Turkey further supports the conclusion that the Turkish government will continue to dissolve parties that are sympathetic to the Kurdish minority. The United Communist Party was formed on June 4, 1990; ten days later, the Chief Prosecutor applied to the Constitutional Court for an order of dissolution. ${ }^{70}$ By ordering the termination of a political party that had yet to participate in general elections, the government deprived society of the ability to debate the party's platform. The ECHR agreed with this view, calling this action "disproportionate to the aim pursued and consequently unnecessary in a democratic society." ${ }^{71}$ It is difficult to fathom how a party that has yet to have any political activity could constitute a legitimate threat to democratic governance. Thus, this outcome demonstrates the government's determination to prevent all public discussion regarding the Kurdish situation in light of its belief that this minority constitutes a significant threat to the unity of the country. As this pattern has continued for several decades, it is likely that parties favoring a solution to the Kurdish situation will continue to face dissolution until the Constitution is amended.

\section{The Near-Dissolution of the Currently Ruling Party}

The Justice and Development Party (“AKP”) currently has a majority of the 550 seats in

Parliament. $^{72}$ In the latest election in 2011, AKP won 327 seats with 49.83 percent of the vote. ${ }^{73}$ Similarly, in the 2007 election, the party won 341 seats with 46.58 of the vote. ${ }^{74}$ Given the popular support this party has garnered over the years, it is remarkable that the party was nearly dissolved in 2008 . When the case involving the closure of the AKP party was brought before the Constitutional Court, the Court was composed of eleven judges; political parties could be dissolved if three-fifths of the Court voted in favor of dissolution. ${ }^{75}$ On May 7, 2010, Turkey took one step in the right direction by amending its Constitution to make it more difficult to dissolve political parties. ${ }^{76}$ Article 146 now indicates that the Constitutional Court will be composed of seventeen members, and Article 149 requires an affirmative vote of two-thirds to dissolve a political party. ${ }^{77}$ Unfortunately for the AKP, its case was brought before these amendments became

\footnotetext{
${ }^{70}$ Olgun Akbulut, Criteria Developed by the European Court of Human Rights on the Dissolution of Political Parties, 34 FordHAM INT'L L.J. 46, 48 (2010).

${ }^{71}$ United Communist Party of Turkey v. Turkey, 1998-I EUR. CT. H.R. ๆ 61.

${ }^{72}$ Background Note: Turkey, U.S. DEPARTMENT OF STATE (Mar. 20, 2012), http://www.state.gov/r/pa/ei/bgn /3432.htm.

${ }^{73}$ Results for Grand National Assembly of Turkey, ELECTION GUIDE, http://electionguide.org/results.php?ID=1628 (last updated Aug. 5, 2011). ${ }^{74}$ Results for Grand National Assembly of Turkey, ELECTION GUIDE, http://electionguide.org/results.php?ID=1147 (last updated Feb. 21, 2006). ${ }^{75}$ UPDATE: A Guide to Turkish Public Law and Legal Research, GLOBALEX, http://www.nyulawglobal.org/globalex/turkey1.htm\#_Constitutional_Amendments (last visited Feb. 1, 2013).

${ }^{76}$ TÜrkiYE CUMHURIYETI ANAYASASI [CONSTITUTION] Nov. 7, 1982, art. 146, 149 (Turk.).

${ }^{77} / d$.
} 
effective. ${ }^{78}$ Thus, if seven out of the eleven judges voted in favor of dissolution, the ruling party of Turkey would be prevented from taking further political action. Luckily for the AKP, it was spared by one vote: six judges voted in favor of dissolution. ${ }^{79}$ The Court concluded that neither the party's program nor statutes supported an anti-secular nation. ${ }^{80}$ Moreover, it could not be established that the party's objective was to destroy democracy or secularism "or to damage the fundamental principles of the constitutional order through the use of violence and intolerance." ${ }^{11}$ It will be interesting to see if these amendments decrease the number of parties banned in Turkey. However, because there are still numerous grounds for dissolution of a political party in Article 68, it is likely that these amendments will spare few, if any, political parties.

\section{The Dissolution of Refah Partisi}

Refah Partisi ("RP"), another Turkish political party, was founded on July 19, 1983 and dissolved fifteen years later on January 16, $1998 .^{82}$ The Constitutional Court dissolved RP because it became a center of activities contrary to secularism, an indispensable attribute of democracy. ${ }^{83}$ In support of this conclusion, the Court looked to the conduct of several party members. To start, it indicated that Refah's chairman had advocated a plurality of legal systems categorizing individuals based on their religious beliefs when he stated, "[t]here must be several legal systems. The citizen must be able to choose ... which legal system is most appropriate for him . . . . In our history there have been various religious movements. Everyone lived according to the legal rules of his own organization, and so everyone lived in peace." ${ }^{84}$ The Court further noted that the chairman advocated a theocratic regime, instituted by force, if necessary. ${ }^{85}$ He made a speech where he stated, "[w]e must ask ourselves . . . whether this change will be violent or peaceful ... . [W]ill it be achieved harmoniously or by bloodshed? The sixty million [citizens] must make up their minds on that point." ${ }^{\prime 86}$ The Court went on to analyze the conduct of several members of parliament. Mr. Sevki Yilmaz called for the country to wage a jihad. ${ }^{87}$ In a public speech, he indicated, "[o]ur mission is not to talk, but to apply the war plan, as soldiers in the army." 88 "Finally, several other members called for a regime based on sharia law, advocating violence if necessary. ${ }^{89}$

\footnotetext{
${ }^{78}$ See Justice and Development Party, E.2008/1 (SPK), K.2008/2, TÜRKİYE CUMHURİYETİ ANAYASA MAHKEMESI [CONSTITUTIONAL COURT OF THE REPUBLIC OF TURKEY] APR. 10, 2012, available aft hittp://www.anayasa.gov.tr/index.php? $1=$ content\&lang $=$ en\&id=137

${ }^{9}$ Akbulut, supra note 70, at 71-72.

${ }^{80}$ Justice and Development Party, supra note 78.

${ }^{81} / d$.

${ }^{82}$ Refah Partisi v. Turkey, 2003-II Eur. Ct. H.R., 9 ฯ 10, 23.

${ }^{83} / d$. बा $23,25$.

${ }^{84} / d$. 928.

${ }^{85} / d$. $\uparrow 31$.

${ }^{86} / d$.

${ }^{87} / d .933$.

${ }^{88} / d .933$.

${ }^{89}$ /d. 9 १ $35-37$.
} 
After analyzing the evidence, the Court concluded that Refah's leaders and members were using their democratic rights and freedoms in an attempt to replace democratic governance with a system based on sharia law. ${ }^{90}$ It went on to state that "[d]emocracy is the antithesis of sharia;" ${ }^{91}$ the rules of sharia are incompatible with the notion of democracy, where secularism prevents the state from manifesting a preference for a particular religious belief. ${ }^{92}$ Consequently, the party was banned, the five members who caused dissolution were stripped of their parliamentary status, and those individuals were prohibited from becoming a member of another political party for five years. ${ }^{93}$

The ECHR was asked to decide whether the dissolution violated the applicant's rights to freedom of association, as guaranteed by Article 11 of the European Convention on Human Rights. ${ }^{94}$ In its decision, the Court stated that the dissolution constituted an interference with the applicants' rights. ${ }^{95}$ The Court further concluded that dissolution was prescribed by law; ${ }^{96}$ although anti-secular activities ceased to be punishable under criminal law, the Turkish Constitution provides that parties may be dissolved for engaging in antisecular conduct. ${ }^{97}$

The next part of the analysis required the Court to determine whether the dissolution

sought to pursue a legitimate aim and whether it was necessary in a democratic society. ${ }^{98}$

Without explanation, the Court indicated that dissolution sought to protect national security and public safety, prevent disorder and crime, and protect the rights and freedoms of others. ${ }^{99}$ Thus, the Court found that the government had a legitimate aim in dissolving RP.

Next, in considering whether the interference was necessary, the Court noted that it must concentrate on three points: (1) whether the risk to democracy was sufficiently imminent; (2) whether the acts and speeches of the party's members could be imputed to the party as a whole; and (3) whether the imputable acts gave a clear picture of the type of anti-democratic society the party advocated. ${ }^{100}$ First, the Court indicated that the risk to democracy was sufficiently imminent in this case; there had been a considerable rise in the party's influence and a strong probability that it would become the ruling party. ${ }^{101}$ In the 1995 general election, for example, RP obtained 22 percent of the votes and received 158 seats in parliament. ${ }^{102}$ In the 1996 local elections, the party obtained

\footnotetext{
${ }^{90} / d .940$.

${ }^{91} / d$.

${ }^{92} / d .924$.

${ }^{93} / d$. 94.

${ }^{94} / d$. 949.

${ }^{95} / d$. 950.

${ }^{96} / d$. 94.

${ }^{97} / d .963$.

${ }^{98} / d$. बा 50-51.

${ }^{99} / d$. 97.

${ }^{100} / d$. 9104.

${ }^{101} / d$. ๆศ 107-110.

${ }^{102} / d$. $\mid 107$.
} 
35 percent of the votes; moreover, an opinion poll indicated that this percentage could have risen to 67 percent within a few years. ${ }^{103}$

As for the second part of the "necessary interference" analysis, the Court concluded that the views and speeches of Refah's members could be imputed to the organization as a whole. ${ }^{104}$ The statements and acts of the chairman "could incontestably be attributed to Refah" because he was the leader of his party, and he had never indicated that the party had opposing views. ${ }^{105}$ The same conclusion was reached in regard to the acts and speeches of party members because their views were never criticized by Refah. ${ }^{106}$

Finally, in the third part of the "necessary interference" test, the Court held that the acts and speeches of the party members set up a clear picture of the type of anti-democratic society the party pursued. ${ }^{107}$ The members advocated a plurality of legal systems that would categorize individuals based on their religious beliefs. ${ }^{108}$ Such a system would be incompatible with the European Convention on Human Rights because such governance would infringe upon the principle of nondiscrimination, one of the fundamental principles of democracy, by treating individuals differently based on their religion. ${ }^{109}$ Moreover, a regime based on sharia would likewise be incompatible with the notion of democracy because it would create a system where religion would intervene in all spheres of public and where women would be treated unequally. ${ }^{110}$

In solidifying its conclusion, the Court indicated that the need to dissolve Refah Partisi was particularly urgent because "Refah did not exclude recourse to force in order to implement its policy". ${ }^{111}$ In addition, the sanction was proportionate to the constitutional violation because only five members lost their seats in parliament; the remaining 152 members continued to pursue their careers. ${ }^{112}$ Consequently, the dissolution of Refah Partisi and the forfeiture of certain political rights did not violate Article 11 of the European Convention on Human Rights. ${ }^{113}$

\section{E. Refah Partisi: An Inconsistent and Unprecedented Outcome}

Although the ECHR supported Turkey's decision to ban RP, this is the only political party dissolution case (with the Republic of Turkey as the respondent state) where the ECHR did not find a violation of Article 11 of the European Convention on Human Rights. ${ }^{114}$ Thus, this unprecedented decision

${ }^{103} / d$.

${ }^{104} / d$. 1115.

${ }^{105} / d$. $\uparrow 113$.

${ }^{106} / d$. $\uparrow 115$.

${ }^{107} / d$.

${ }^{108} / d$. $\mid 119$.

${ }^{109} / d$.

${ }^{110} / d$. 9123.

${ }^{111} / d$. 132.

${ }^{112} / d$. 133.

${ }^{113} / d$. 9136.

${ }^{114}$ For cases holding that the party dissolution was a violation of the Convention, see, e.g., Fazilet Partisi and Kutan v. Turkey, App. No. 1444/02, Eur. Ct. H.R. (2006); Democracy and Change 
does not indicate that Turkey's law on political parties is aligned with European standards, and consequently, the ease with which political parties can be banned will continue to inhibit Turkey's accession into the European Union. However, it then becomes a matter of distinguishing this case from other dissolution cases. From an outsider's prospective, it appears that the ECHR was alarmed by the party's willingness to use force to achieve a new form of governance incompatible with democracy. ${ }^{115}$ The Court stressed that a system of governance based on sharia law would be contrary to the principles of democracy. ${ }^{116}$

In addition, it condemned the use of force to achieve a political objective. ${ }^{117}$ Although the Court strongly believes that democracy is incompatible with governance based on sharia law, it cannot be said that the holding would be the same had the party's members stressed a transition through peaceful means. After all, the Court has stressed that "freedom of expression as enshrined in Article 10 is applicable ... not only to 'information' or 'ideas' that are favorably received or regarded as inoffensive or as a matter of indifference, but also to those that offend, shock or disturb."118 Thus, in the Court's perspective, although sharia law may appear to be utterly incompatible with the notion of democratic governance, political parties have a right to debate the preferred form of governance.

Moreover, the Court has stressed that in considering whether to ban a party, an important factor to take into consideration is the party's willingness to resort to violence to achieve its political objectives. ${ }^{119}$ The ECHR has indicated that it "finds nothing in [the party's program] that can be considered a call for the use of violence, an uprising or any other form of rejection of democratic principles. That, in the Court's view is an essential factor to be taken into consideration." ${ }^{120}$ Consequently, it appears that the advocacy of a system of governance incompatible with democracy, coupled with the threat of violence to achieve that objective, is reprehensible enough to uphold the Constitutional Court's decision to ban RP.

\section{F. $\quad$ European Standards Regarding the Closure of Political Parties}

Although Turkey has implemented several reforms to make it more difficult to dissolve

Party, Eur. Ct. H.R.; Yazar and Others v. Turkey, 2002-II Eur. Ct. H.R./; Dicle on Behalf of the

Democratic Party, Eur. Ct. H.R.; Freedom and Democracy Party v. Turkey, 1999-VII EUR. CT.

H.R.; United Communist Party of Turkey v. Turkey, 1998-I EUR. CT. H.R.; Socialist Party and

Others v. Turkey, 1998-III Eur. Ct. H.R.

${ }^{115}$ Refah Partisi v. Turkey, 2003-II Eur. Ct. H.R., 9 ศा 123,129.

${ }^{116} / d$. $₫ 123$.

${ }^{117}$ Id. $\uparrow 132$.

${ }^{118}$ United Communist Party of Turkey, 1998-I EuR. CT. H.R., 943.

${ }^{119}$ See Freedom and Democracy Party, Eur. Ct. H.R., $\uparrow 40$

${ }^{120}$ Id.; Bulent Algan, Dissolution of Political Parties by the Constitutional Court in Turkey: An Everlasting Conflict Between the Court and the Parliament?, 60 ANKARA ÜNIVERSITESI HUKUK FAKÜLTESI DERGISI 809, 821 (2011). 
political parties, further reforms are necessary before its law will conform with European

standards. The Venice Commission, an advisory body of the Council of Europe, indicated that there are a number of common features, despite wide diversity, among European countries with regard to provisions governing political party activity. ${ }^{121}$ To begin, the authority to initiate a prohibition procedure is rarely entrusted with the prosecuting authorities. ${ }^{122}$ Such a decision should be discretionary, as initiating the procedure itself may have grave consequences (due to the sensitivity of cases restricting fundamental rights). ${ }^{123}$ Thus, in the countries with rules on party dissolution, the decision to initiate a proceeding is largely political. ${ }^{124}$ In Germany, for example, the decision lies with the Federal Government, the Federal Parliament, or the Federal Council. ${ }^{125}$ Because Turkey is unique in that competence lies with the Chief Public Prosecutor, ${ }^{126}$ the Commission believes that the procedural aspect of dissolution is not in line with European standards. ${ }^{127}$ By providing one individual with this authority, the entire procedure is left up to one man or woman's unfettered discretion, without a democratic check or balance. ${ }^{128}$

The Commission also examined European standards regarding the criteria for prohibiting and dissolving political parties. ${ }^{129}$ It concluded that there are several national requirements, including, but not limited to, organizations that threaten the existence or sovereignty of the state or its basic democratic order; that foster social, ethnic, or religious hatred; that use or threaten to use violence; that are fascists or Nazis; and those that are criminal associations. ${ }^{130}$

Although the national requirements vary depending on historical experience, the Commission indicated that no European system includes all of these criteria, and the majority of the systems includes only one or two. ${ }^{131}$ Turkey, however, lists eight criteria in Article 68 of the Constitution, some of which are listed in broad terms, leaving room for manipulation. ${ }^{132}$

Another broad distinction the Commission draws is the frequency with which dissolution is sought. The Commission indicated, "in Turkey a high number of political parties have been prohibited over the years. This [is in stark] contrast with the prevailing European approach, under which political parties are prohibited or dissolved only in exceptional cases." 133 In Europe, there have been

\footnotetext{
${ }^{121}$ Opinion on the Constitutional and Legal Provisions Relevant to the Prohibition of Political Parties in Turkey, Eur. COMm'N For Democracy Through Law (VENice COMM'N), No. 489/2008 of 13 Mar. 2008, ๆ 15 [hereinafter Opinion].

${ }^{122} / d$. $₫ 33$.

${ }^{123} / d$.

${ }^{124} / d$. $₫ 34$.

${ }^{125} / d$.

${ }^{126}$ TÜRKIYE CUMHURIYETİ ANAYASASI [CONSTITUTION] Nov. 7, 1982, art. 69 (Turk.).

${ }^{127}$ See Opinion, supra note 121, \ 35.

${ }^{128} / d$. बा 35,86

${ }^{129} /$ d. १ศा 23-30.

${ }^{130} / d$. $₫ 23$.

${ }^{131} / d$. 925.

${ }^{132}$ Id. ๆ $\uparrow$ 73-74; TÜRkIYE CUMHURIYETI ANAYASASI [CONSTITUTION] Nov. 7, 1982, art. 68 (Turk.).

${ }^{133}$ Opinion, supra note 121, ฯ 3.
} 
few dissolutions, and each concerned marginal and extremist parties in Germany and Spain. ${ }^{134}$ Thus, outside Turkey, this remedy is utilized only in exceptional circumstances. In the Commission's view, a remedy as extreme as dissolution should be used only when there is a threat of or use of violence. ${ }^{135}$ Although this standard is somewhat stricter than that in most European countries, the ECHR seems to support this view, upholding dissolution in Refah Partisi because of the threat of violence to instill an undemocratic regime. ${ }^{136}$

\section{G. Conclusions on Political Party Closure in Turkey}

It is unlikely that Turkey will become a member of the European Union in the foreseeable future because of the dissimilarities that exist between its political party dissolution laws and that of other European nations. For Turkey to complete its accession negotiations, it will need to align its laws with those of the European Union in thirty-five subject-related chapters. ${ }^{137}$ Because political parties are essential to effective democratic governance, Turkey will likely experience difficulty in completing the "judiciary and fundamental rights" chapter. ${ }^{138}$ Although there is a permitted margin of appreciation (a doctrine the court uses to take into consideration that the Convention may be interpreted differently in each member state), because of the diversity among European nations, Turkey's law appears to be too distinct, and thus, incapable of reconciliation with the European standard. Therefore, it is unlikely that the European Commission will open, let alone close the chapter on "judiciary and fundamental rights" until Turkey's law is reformed.

The European decision-making bodies unanimously agree that Turkey needs to reform its law. The European Commission has stressed that Turkey needs to bring its political party closure law in line with European standards. ${ }^{139}$ The Venice Commission similarly concluded that Turkey's political party "reforms have not been sufficient to fully bridge the gap between the Turkish rules and the standards of the ECHR and the Venice Commission." ${ }^{140}$ Because of the consensus of opinion among the international community, Turkey will need to narrow the gap between its law and those of other European countries before it will be admitted into the European Union.

\section{Freedom of Religion in Turkey}

\section{A. The Law}

Although Turkey's law regarding freedom of religion is more in line with European standards than its law regarding the dissolution of political parties, the

${ }^{134} / d$. $\llbracket 27$.

${ }^{135} / d$. $₫ 58$.

${ }^{136} / d$. 95 ; see Refah Partisi v. Turkey, 2003-II Eur. Ct. H.R.

${ }^{137}$ Steps Towards Joining, supra note 12.

${ }^{138} / d$.

${ }^{139}$ Commission Staff Working Paper: Turkey 2011 Progress Report, supra note 34, at 9.

${ }^{140}$ Opinion, supra note 121 , ๆ 110. 
European Commission continues to pressure Turkey to uphold its constitutional protections. ${ }^{141}$ The Turkish Constitution provides that "[e]veryone has the right to freedom of conscience, religious belief and conviction. Acts of worship, religious services, and ceremonies shall be conducted freely, provided that they do not violate the provisions of Article 14." ${ }^{142}$ Article 14 further provides that the rights and freedoms provided for in the Constitution shall not "be exercised with the aim of violating the indivisible integrity of the state with its territory and nation, and endangering the existence of the democratic and secular order of the Turkish Republic based upon human rights." ${ }^{143}$ Although Article 14 seems to diminish freedom of religion, this limitation is consistent with European standards because its objective is to impose limitations on individual rights and freedoms when necessary to protect the interests of society as a whole. ${ }^{144}$

\section{B. Case of Hasan and Eylem Zengin v. Turkey}

Turkey's law on freedom of religion is inconsistent with European standards regarding compulsory religious education in primary and secondary schools. ${ }^{145}$ Turkey's Constitution provides that "[i]nstruction in religious culture and moral education shall be compulsory in the curricula of primary and secondary schools. Other religious education and instruction shall be subject to the individual's own desire, and in the case of minors, to the request of their legal representatives." ${ }^{146}$

Because of this law, Hasan Zengin and his daughter, Eylem Zengin, submitted a request to the Provincial Directorate of National Education seeking an exemption from the religious culture and ethics courses. ${ }^{147}$ The Zengins were adherents to Alevism, a branch of Islam that differs from Sunni Islam in many aspects. For example, adherents to Alevism reject the sharia law, defend women's rights, and express their devotion through song and dance instead of attending a mosque. The Zengins felt that their family should be exempt from religious courses because the compulsory nature of the education was contrary to secularism. ${ }^{148}$ Moreover, the Universal Declaration of Human Rights allows parents to choose the type of education their children receive. ${ }^{149}$ Their exemption request was denied because the Turkish Constitution expressly provides for compulsory religious education in primary and secondary schools. ${ }^{150}$

${ }^{141}$ See Commission Staff Working Paper: Turkey 2011 Progress Report, supra note 34, at 89

("[F]urther significant efforts are needed in most areas, in particular . . freedom of religion.").

${ }^{142}$ TÜRKIYE CUMHURIYETI ANAYASASI [CONSTITUTION] Nov. 7, 1982, art. 24 (Turk.).

${ }^{143} / d$. art. 14.

${ }^{144}$ See European Convention for the Protection of Human Rights and Fundamental Freedoms, art.

9(2), opened for signature Nov. 4, 1950, 213 U.N.T.S. 221 (entered into force Sept. 3, 1953).

${ }^{145}$ Zengin v. Turkey, App. No. 1448/04, EUR. CT. H.R. (2008), 971.

${ }^{146}$ TÜRKIYE CUMHURIYETI ANAYASASI [CONSTITUTION] Nov. 7, 1982, art. 24 (Turk.).

${ }^{147}$ Zengin, Eur. Ct. H.R., 910.

${ }^{148}$ /d. Фศा 8-10.

${ }^{149} / d$. $\uparrow 10$.

${ }^{150} / d$. $\uparrow \uparrow 11-13$. 
Following this denial, the applicants brought their claims to the ECHR, alleging a violation of Article 2 of Protocol 1 of the European Convention on Human Rights. ${ }^{151}$ Similar to the Universal Declaration, Article 2 provides that a state must respect parents' rights to ensure their children receive education in accordance with their religious beliefs. ${ }^{152}$ In response to this allegation, the ECHR noted that its case law indicates that the objective of Article 2 is to ensure pluralism in education, an essential characteristic for democratic governance. $^{153}$ Thus, although the court acknowledged that educational curricula falls within the competence of state parties, a state may not "pursue an aim of indoctrination" that could be perceived as disregarding parents' religious beliefs. ${ }^{154}$ It explained that a democratic society has an obligation to be impartial and neutral towards various religious beliefs to ensure pluralism. ${ }^{155}$

In order to decide whether the curriculum is taught objectively, the ECHR looked to the religious course syllabus and textbooks. According to the syllabus, the subject matter was to be taught in accordance with the principles of secularism and in a way that would "foster a culture of peace and a context of tolerance."156 Thus, these objectives were compatible with the principles incorporated in Article 2 through the ECHR's case law. ${ }^{157}$ However, the Court went on to note that the syllabus provided for instruction on the Koran and Mohamed; likewise, the seventh grade syllabus provided for instruction on several fundamental aspects of Islam. ${ }^{158}$ The issue became more problematic after the ECHR examined the textbooks used by the Turkish government in primary and secondary education. These textbooks did not provide a general overview of the world religions; rather, they "provide[d] instruction in the major principles of the Muslim faith ... such as the profession of faith, the five daily prayers, Ramadan, [and] pilgrimage."159 In addition, students must take exams on the Koran and the daily prayers. ${ }^{160}$ The ECHR went on to conclude that although Turkey gives priority to the Islamic faith, it is the majority religion in the country, and thus, Islam-focused religious instruction alone cannot be viewed as indoctrination. ${ }^{161}$

This, however, was not the end of the analysis: the ECHR considered the allegation that no instruction was provided on the Alevi faith. ${ }^{162}$ It noted that a large portion of the Turkish population adheres to Alevism. ${ }^{163}$ Thus, because Alevism was not taught and religious instruction was heavily focused on Sunni

${ }^{151} / d$. ๆ甲 1,35 .

${ }^{152} / d . \uparrow 35$.

${ }^{153} / d$. 48.

${ }^{154} / d$. $\uparrow \uparrow 51-52$.

${ }^{155} / d$. $\uparrow 54$.

${ }^{156} / d$. $\uparrow 58$

${ }^{157} / d$. 959.

${ }^{158} / d$. $\uparrow 60$.

${ }^{159}$ Zengin, Eur. Ct. H.R., \ 61.

${ }^{160} / d$. 962.

${ }^{161} / d$. 963.

${ }^{162} / d$. 965 .

${ }^{163} / d$. $\mid 67$. 
Islam, ${ }^{164}$ Turkey's curriculum did not meet Article 2's requirement of objectivity as required by the case law. Finally, the ECHR decided whether Turkey's law respects parents' religious views. ${ }^{165}$ If the law allows children to be exempted from religious courses, the Sunni Islam-heavy curriculum would be permitted (in light of the fact that 99 percent of the Turkish population adheres to the Muslim faith) as long as it became more objective. ${ }^{166}$ In 1990, Turkey's Supreme Council for Education indicated that children who adhere to the Jewish or Christian faith could apply for an exemption. ${ }^{167}$ The Court concluded that this exemption procedure did not provide sufficient guarantees to concerned parents. ${ }^{168}$ Requiring students to reveal their religious affiliation to apply for an exemption poses a problem under both the Turkish Constitution and Article 9 of the Convention. ${ }^{169}$ Moreover, by disallowing the possibility of exemption to the Muslim faith, the government was indirectly acknowledging that Islam heavily influenced the curriculum. ${ }^{170}$ Lastly, because the decision to exempt was discretionary, there were no obligatory safeguards for parents who have religious beliefs different from those taught. ${ }^{171}$

\section{Conclusions on Compulsory Religious Education in Turkey}

Turkey's failure to change its practice regarding compulsory religious education will likely hamper the country's accession into the European Union. Unlike Turkey, almost all European states allow students to opt out of compulsory religious courses or make attendance optional. ${ }^{172}$ Thus, Turkey will have difficulty concluding negotiations on chapter twenty-threejudiciary and fundamental rights - until it can adequately protect religious freedom, a hallmark of modern-day democracies. ${ }^{173}$ Moreover, negotiations on this chapter have yet to be opened; thirteen out of thirty-five chapters have been opened (one has been closed), but chapter twenty-three remains untouched. ${ }^{174}$ In addition to the lack of progress over the last six-and-a-half years, ${ }^{175}$ the European Commission continues to criticize Turkey for its failure to implement the Zengin decision. In its 2010 report, the Commission indicated that Turkey had not yet implemented the Zengin judgment, which requested Turkey to conform to Article 2 after finding that classes did not give a general overview of world

\footnotetext{
${ }^{164} / d$. 967 (noting that "the life and philosophy of two individuals who had a major impact on [Allevism's] emergency are taught in the 9th grade is insufficient to compensate for the shortcomings of this teachings.")

${ }^{165} / d$. $\uparrow 71$.

${ }^{166} / d$. 971 .

${ }^{167} / d .972$.

${ }^{168} / d$. 976.

${ }^{169} / d$. 97.

${ }^{170} / d$. 974.

${ }^{171} / d$. 975 .

$172 / d$. 771

${ }^{173}$ Steps Towards Joining, supra note 12; see, e.g., Sahin v. Turkey, 2005-XI Eur. Ct. H.R., ๆ 104; ZHOU, supra note 36; DEMOCRACY WEB, supra note 36.

${ }^{174}$ Commission Staff Working Paper: Turkey 2011 Progress Report, supra note 34, at 29.

${ }^{175}$ Accession negotiations with Turkey began in October. 2005. Turkey, supra note 22.
} 
religions but "provided specific instruction in the guiding principles of the Muslim faith." 176 This disfavor carried over to the 2011 progress report; the ECHR indicated that although the Ministry of National Education prepared new textbooks that will include information on Alevism, religious courses remain compulsory under Turkish law. ${ }^{177}$ Furthermore, the Commission pointed out that the Zengin decision remains unimplemented, exemptions are rare, alternative classes are not provided for exempted students, and there have been reports that students who do not attend religious courses receive lower grades. ${ }^{178}$

\section{Sahin v. Turkey: the Headscarf Case}

As with Refah Partisi, Sahin demonstrates the European Court of Human Rights' willingness to consider Turkey's unique religious atmosphere when determining how far to allow it to stray from European standards. The circumstances of the headscarf case are as follows. Leyla Sahin was a fifthyear medical student studying at the Cerrahpasa Faculty of Medicine at Istanbul University. ${ }^{179}$ She completed her first four years at the Faculty of Medicine at Bursa University and wore the Islamic headscarf daily. ${ }^{180}$ However, during her time at Istanbul University, the university issued a circular that required faculty to prohibit students wearing the Islamic headscarf from attending lectures, tutorials, and courses. ${ }^{181}$ In accordance with this circular, Ms. Sahin was denied access to an examination and lecture and was also prohibited from enrolling in classes for the following semester. ${ }^{182}$ Despite warnings, Ms. Sahin continued to wear her headscarf and was consequently suspended for a semester after taking part in a protest against the school dress code. ${ }^{183}$ She tried unsuccessfully to get the administration to annul the circular; ${ }^{184}$ she then left the school to continue her studies at Vienna University. ${ }^{185}$

Ms. Sahin took her case to the European Court of Human Rights, arguing "that the ban on wearing the Islamic headscarf in institutions of higher education constituted an unjustified interference with her right to freedom of religion, in particular, her right to manifest her religion." ${ }^{186}$ The court began with the premise that the circular interfered with the applicant's right to manifest her religion in a particular place, a university. ${ }^{187}$ In deciding whether the interference

\footnotetext{
${ }^{176}$ Commission Staff Working Document: Turkey 2010 Progress Report, supra note 34, at 23.

${ }^{177}$ Commission Staff Working Paper: Turkey 2011 Progress Report, supra note 34, at 29.

${ }^{178} / d$.

${ }^{179}$ Sahin v. Turkey, 2005-XI Eur. Ct. H.R., 15.

${ }^{180} / d$.

${ }^{181} / d .916$

${ }^{182} / d$. 17.

${ }^{183}$ /d. ๆ $22-24$

${ }^{184} / d$. $\mid$ | $18-20$.

${ }^{185}$ /d. $\mid 28$ (Her suspension was later annulled when law number 4584 was passed. Law number 4585 "provided for students to be given an amnesty in respect of penalties imposed for disciplinary offenses and for any resulting disability to be annulled," but she decided to pursue her studies elsewhere, nevertheless.).

${ }^{186} / d$. 970.

${ }^{187}$ Id. 978.
} 
was prescribed by law, the court reiterated its case-law, indicating that the term "prescribed by law" means a basis in domestic law that is both accessible and understandable in a way that would allow the individual to foresee the consequences of a given action. ${ }^{188}$ Thus, in contending that the restriction was not prescribed by law, Ms. Sahin argued that the law was inconsistent, and therefore, the consequences of an action were unforeseeable because the circular was incompatible with Section 17 of Law Number 2547. Section 17 provides, "[c] hoice of dress shall be free in institutions of higher education, provided that it does not contravene the laws in force." ${ }^{189}$ The Court held that "law" includes statutory law and case law, and a year after Section 17 of Law Number 2547 was enacted, the Constitutional Court of Turkey indicated that authorizing women to wear headscarves in universities is contrary to the notion of secularism. ${ }^{190}$ This decision was binding and published in the Official Gazette. ${ }^{191}$ Moreover, the school adopted memorandums and resolutions well before the applicant enrolled there; ${ }^{192}$ these documents indicated that the Constitutional Court ruled that religious attire may not be worn in universities. ${ }^{193}$ Thus, it should have been clear to Ms. Sahin that she would be refused access to classes and examinations if she did not remove her headscarf. ${ }^{194}$

In deciding whether the restriction sought to pursue a legitimate aim, the court stated that the restriction was implemented to protect the rights and freedoms of others and to protect public order. ${ }^{195}$ The Court did not elaborate on this point, but the Court appears to agree with Turkey's proposition that prohibiting the headscarf prevents the state from favoring one religion over another. ${ }^{196}$ Finally, the Court was left to decide whether this restriction was necessary in a democratic society. ${ }^{197}$ The Court stated, "[i]n democratic societies . . . it may be necessary to restrict freedoms to manifest one's religion or belief in order to reconcile the interests of the various groups and ensure that everyone's beliefs are respected."198 It is important that the state demonstrates mutual tolerance for all religious beliefs, and thus remains impartial. ${ }^{199}$ In addition, because there is currently no uniform standard in Europe regarding the significance of religion in society or the proper relationship between religion and the state, permitted limitations are decided on a case-by-case basis. $^{200}$ Thus, states are allowed a margin of appreciation in deciding what measures to implement. ${ }^{201}$ Through this reasoning, the limitations were upheld in

\footnotetext{
${ }^{188} / d$. ๆ 84.

${ }^{189} / d$. 940.

${ }^{190} / d$. qा $41,88$.

${ }^{191} / d$. $\uparrow 93$ (Legislation in Turkey is published in the Official Gazette before it goes into effect.).

${ }^{192} / d$. 997.

${ }^{193} / d$. 945.

${ }^{194} / d$. 988.

${ }^{195} / d$. $\uparrow 99$.

${ }^{196} / d$. |qा 39, 99.

${ }^{197}$ /d. 999.

${ }^{198} / d$. 106.

${ }^{199}$ Id. I 107.

${ }^{200} / d$. 109.

${ }^{201} / d$.
} 
this case. The Court emphasized that because the majority of the population is Muslim, and the headscarf is seen as a compulsory religious obligation, students who choose not to wear it may be deprived of their free will upon seeing others who comply with this religious duty. ${ }^{202}$ Similarly, prohibiting the headscarf prevents the state from manifesting a preference for a particular religious belief, which is an important notion in Turkey because of its long-standing struggle to separate religion from the political discourse. ${ }^{203}$

Lastly, the Court had to decide whether the means pursued to achieve the objective were proportional. ${ }^{204}$ It held this condition was satisfied because practicing Muslims are free to manifest their religion outside the university environment. $^{205}$ In addition, headscarves are not the only religious symbol prohibited in universities; other religious attire is similarly banned. ${ }^{206}$ Consequently, there was no breach of Article 9 of the Convention, which protects an individual's right to manifest his or her religious beliefs. ${ }^{207}$

\section{E. Sahin v. Turkey: Another Refah Partisi?}

Because of the utmost importance of freedom of religion in democratic societies, it is surprising that the European Court of Human Rights upheld Turkey's decision to ban the headscarf on university campuses. The distinguishing factor in this case appears to be the permitted margin of appreciation when it comes to limiting freedom of religion. ${ }^{208}$ In Europe, there is no consensus on the proper relationship between the church and the state, and there is wide diversity in the degree to which headscarves are regulated. ${ }^{209}$ In France, for example, the notion of secularism is incorporated into the Constitution, and French law prohibits students in state primary and secondary schools from wearing religious attire that "overtly manifest[s] a religious affiliation." ${ }^{210}$ On the other hand, students are permitted to wear the headscarf in countries such as Austria, Germany, the Netherlands, Spain, Sweden, Switzerland, and the United Kingdom. ${ }^{211}$ The Netherlands goes a step further and permits teachers to wear the headscarf. ${ }^{212}$

Because member states' laws vary on the permissibility of wearing headscarves in the school environment, the willingness of the court to restrict freedom to manifest one's religious beliefs is fathomable.

\footnotetext{
${ }^{202} / d$. 115 .

${ }^{203} / d$. 1113.

${ }^{204} / d$. 1117.

${ }^{205} / d$. 1118.

${ }^{206} / d$.

${ }^{207} / d .9123$

${ }^{208}$ Id. 9109 ; Aernout Nieuwenhuis, European Court of Human Rights: State and Religion, Schools and Scarves, An Analysis of the Margin of Appreciation as Used in the Case of Leyla Sahin v. Turkey, Decision of 29 June 2004, Application Number 44774/98, 1 EUR. CONST. L. REV. 495 (2005).

${ }^{209}$ Sahin, 2005-XI Eur. Ct. H.R., $₫ 109$; Nieuwenhuis, supra note 208, at 495, 502.

${ }^{210}$ Sahin, 2005-XI Eur. Ct. H.R., 9 \$54, 56; see also Nieuwenhuis, supra note 208, at 495.

${ }^{211}$ Sahin, 2005-XI Eur. Ct. H.R., $₫ 58$.

${ }^{212}$ Nieuwenhuis, supra note 208, at 495.
} 
The European Court of Human Rights is not merely a state court that upholds state notions of religious freedom, but it is also a supranational court that must look to the standards in various countries when creating its case law. When there is not a uniform view on a particular issue, it appears the ECHR is willing to give the respondent state a margin of appreciation in deciding what policies are appropriate to protect the rights of society as a whole. The Court also appears to respect the notion of state sovereignty until there is a clear consensus on the ability of states to regulate religious attire.

\section{F. $\quad$ Arslan v. Turkey: Imposing Limits on Sahin v. Turkey}

Arslan v. Turkey demonstrates that the European Court of Human Rights is unwilling to permit states to stray too far from the rights guaranteed in Article 9 of the Convention. In this case, Mr. Ahmet Arslan and 126 Turkish nationals belonged to Aczimendi tarikaty, a religious group. ${ }^{213}$ In October 1996, they met for a religious ceremony. Afterwards, they toured the Ankara streets "while wearing the distinctive dress of their group, which . . . was made up of a turban, 'salvar' (baggy 'harem' trousers), a tunic and a stick." ${ }^{214}$ They were arrested and convicted of violating laws that prohibit headgear and religious attire from being worn in public other than for religious ceremonies. ${ }^{215}$ Because of these convictions, Mr. Ahmet Arslan and the other Turkish nationals petitioned the European Court of Human Rights claiming that the convictions violated Article 9 of the Convention. ${ }^{216}$

In determining whether there was a violation of Article 9, the Court held that there was an interference with the right to manifest one's religion. ${ }^{217}$ It also held that the interference was prescribed by law and "pursued the legitimate aims of protection of public safety, prevention of disorder and protection of the rights and freedoms of others." ${ }^{218}$ However, Turkey was unable to establish the necessity of this interference in a democratic society. ${ }^{219}$ The applicants were punished solely for wearing religious attire in a public place. ${ }^{220}$ Moreover, there was no evidence that the group constituted a threat to public order or sought to exert their religious views on others. ${ }^{221}$ In addition, the applicants did not hold an official status, and thus, laws concerning civil servants

\footnotetext{
${ }^{213}$ Chamber Judgment Ahmet Arslan and Others v. Turkey- Press Release Issues by the Registrar 23.02.10, STRASBOURG CONSORTIUM: FREEDOM OF CONSCIENCE AND RELIGION AT THE EUROPEAN COURT OF HUMAN Rights, 1 (Feb. 23, 2010)

http://strasbourgconsortium.org/document.php?DocumentID= 4732 [hereinafter Ahmet Ars/an and Others v. Turkey].

${ }^{214} / d$.

${ }^{215} / d$.

${ }^{216} / d$. at 2 .

${ }^{217} / d$.

${ }^{218} / d$. at 2.

${ }^{219}$ Ahmet Arslan and Others v. Turkey, supra note 213, at 2-3.

${ }^{220} / d$. at 2.

${ }^{221}$ Id.; Dominic McGoldrick, Religion in the European Public Square and in European Public

Life-Crucifixes in the Classroom? 11 HUM. RTS. L. REV. 451, 495-96 (2011).
} 
were inapplicable. $^{222}$ Finally, as opposed to other cases where freedom to manifest one's religion was subject to restrictions, these individuals were not convicted of wearing religious attire in a public establishment where religious neutrality might trump the freedoms laid out in Article 9. ${ }^{223}$ For these reasons, six of the seven judges voted that the convictions violated Article $9 .^{224}$

\section{Conclusion}

It is unlikely that Turkey will become a member of the European Union in the foreseeable future because it is unwilling to effectively protect freedom of association and freedom of religion. In regards to the dissolution of political parties, both the European Commission and the Venice Commission agree that significant constitutional reform is needed to align Turkey's law with European standards. $^{225}$ Although several European countries have guidelines that provide for dissolution in exceptional circumstances, these laws are rarely effectuated. $^{226}$ Specifically, the Venice Commission noted that outside Turkey, dissolution laws were implemented solely to ban marginal and extremist parties in Germany and Spain. ${ }^{227}$ Thus, because the international community condemns the excessive manner in which Turkey has utilized its dissolution law, it is unlikely that the European Commission will open, let alone close the "judiciary and fundamental rights" chapter. $^{228}$ The particular importance of political parties "in ensuring pluralism and the proper functioning of democracy" strengthens this conclusion. 29

Additionally, Turkey's failure to adequately protect freedom of religion will equally prevent negotiations on the "judiciary and fundamental rights" chapter. ${ }^{230}$ In regards to compulsory religious education, the European Commission continues to condemn Turkey for its failure to implement the Zengin decision. ${ }^{231}$ This denouncement stems from Turkey's digression from the European standard: almost all European countries permit students to opt out of religious education or make attendance optional. ${ }^{232}$ Furthermore, Turkey is too willing to restrict freedom to manifest one's religious beliefs. Although the European Court of Human Rights upheld Turkey's decision in Sahin $v$. Turkey, ${ }^{233}$ this departure from its past holdings appears to be the result of the permitted margin of appreciation when it comes to limiting freedom of

\footnotetext{
${ }^{222}$ McGoldrick, supra note 221, at 496.

${ }^{223}$ Id.; Ahmet Arslan and Others v. Turkey, supra note 213, at 2.

${ }^{224}$ Ahmet Arslan and Others v. Turkey, supra note 213, at 3.

${ }^{225}$ Commission Staff Working Paper: Turkey 2011 Progress Report, supra note 34, at

9; Opinion, supra note 122, $₫ 110$.

${ }^{226}$ Opinion, supra note 121 , at 6.

${ }^{227} / d$.

${ }^{228}$ Steps Towards Joining, supra note 12.

${ }^{229}$ United Communist Party of Turkey v. Turkey, 1998-I EUR. CT. H.R., ๆ 43.

${ }^{230}$ Steps Towards Joining, supra note 12.

${ }^{231}$ Commission Staff Working Document: Turkey 2010 Progress Report, supra note 34, at 23; Commission Staff Working Paper: Turkey 2011 Progress Report, supra note 34, at 29.

${ }^{232}$ Zengin v. Turkey, App. No. 1448/04, EUR. CT. H.R., ๆ 71.

${ }^{233}$ Sahin v. Turkey, 2005-XI Eur. Ct. H.R.
} 
religion. ${ }^{234}$ In Europe, there is no consensus on the proper relationship between the church and the state, and there is also wide diversity in the degree to which countries regulate headscarf wear. ${ }^{235}$ However, the ECHR was unwilling to allow Turkey to stray too far from freedom to manifest one's religion: the court denounced Turkey's decision to impose sanctions on individuals who wore religious attire in a public area. ${ }^{236}$ Thus, overall, the ECHR appears to believe that Turkey's law needs to be aligned with European standards. Consequently, it is unlikely Turkey will gain admission to the European Union until it can adequately protect religious freedom, a hallmark of modern-day democracies. ${ }^{237}$

It is also unlikely that Turkey will gain admission to the EU because accession requires a unanimous vote by all members of the European Union. ${ }^{238}$ Thus, even if this chapter is eventually closed, achieving a unanimous vote in favor of accession is improbable because several countries, notably France and Germany, adamantly oppose Turkish accession. ${ }^{239}$ Until Turkey can persuade the union that it belongs among the European countries and that it is capable of reforming its laws to meet European standards, Turkey will remain outside this supranational organization.

${ }^{234} / d$. 9109 ; Nieuwenhuis, supra note 208.

${ }^{235}$ Sahin, 2005-XI Eur. Ct. H.R., ๆ 109; Nieuwenhuis, supra note 208, at 495, 502.

${ }^{236}$ Ahmet Arslan and Others v. Turkey, supra note 213.

${ }^{237}$ See, e.g., Sahin, 2005-XI Eur. Ct. H.R., ๆ 104; ZHOU, supra note 36; DEMOCRACY

WEB, supra note 36.

${ }^{238}$ Steps Towards Joining, supra note 12; Enlargement of the European Union

Factsheet, supra note 38.

${ }^{239} \mathrm{Kettle}$, supra note 39; Turkey's EU Bid on the Rocks as Tensions with Greek Cypriots

Escalate, supra note 39. 